\title{
A Study on the Reform of Tax System that
}

\section{Drives Enterprises’ Self-Innovation}

\author{
Shuqing Li \\ School of Business Administration, North China Electric Power University, Beijing 102206, China \\ E-mail: lshqing@sina.com
}

\begin{abstract}
Enterprises' ability of self-innovation determines the fate of one country or nation. The 5th Plenum of 16th CPC Central Committee advocates enhancing Chinese enterprises' self-innovation, which is an important strategic decision, aiming at prospering Chinese nationality. Self-innovation determines China's Advantage of Backwardness. From this point of view, this paper argues that present tax policies in China could not support the self-innovation enterprises strongly because of deficiencies in regulations of income tax and value-added tax. Finally, based on introducing the tax policies that support self-innovation enterprises in foreign countries, this paper puts forward relevant countermeasures and suggestions for the reform of China's tax system. For example, reform the income tax and value-added tax. At the same time, official branches should impose strict supervision on tax, avoiding enterprises illegally taking advantages over China's favorable tax policies.
\end{abstract}

Keywords: Self-innovation, Tax system, Advantage of Backwardness

CPC Proposals for formulating the 11th Five-Year Plans for National Economic and Social Development issued in the 5th Plenum of 16th CPC Central Committee point out important strategic decisions in order to prosper Chinese nationality based on the new features of China economic development. Implement the strategy of developing China by science-education and strengthening China by talents perfectly. Take the enhancement of self-innovation as the strategic base for science \& technology development, and the central ring of industrial structure adjustment and growth mode transform. Improve the abilities of initial innovation, integrated innovation, and re-innovation after the introduction of foreign latest technology. In order to reach this target, official sections at different levels should cooperate closely and provide with policy support. This paper makes explorations on the reform of tax system that benefits self-innovation.

\section{Self-innovation determines China's Advantage of Backwardness.}

"Innovation" was firstly put forward by Schumpeter, an Austria economist. In 1912, Schumpeter advanced the systematic innovation theory in his work The Theory of Economic Development for the fist time. In his opinion, technological innovation refers to managers re-combining production factors. The new combination includes five aspects. (1) Develop a new product or new quality; (2) Adopt a new production method; (3) Explore a new market; (4) Obtain a new supply source of raw materials or finished products; (5) Realize a new organizational form. Schumpeter also thought that there was close relationship between innovation and economic growth, and the target of innovation was to increase economic effectiveness.

According to the spirits of the 5th Plenum of 16th CPC Central Committee, self-innovation has three meanings. One is the initial innovation, namely being the first one who generates new theory, new method, new product, new handcraft, new organization, etc. The second is the integrated innovation, namely combining relevant technologies and management methods organically to form new technology and new way. The third is the re-innovation after introduction and assimilation, namely assimilating, absorbing, and reforming the introduced technologies and management methods to form new technology and new management way. There-into, the third is common in developing countries, which is also the most proper way for China at present.

Self-innovation is vital for China's economic development. It determines China's Advantage of Backwardness. The Advantage of Backwardness is firstly put forward by evolvement economics. According to a history economist, the Advantage of Backwardness is especially possessed by developing countries that lag behind developed countries in economic development (Genliang Jia, 2004). And developed countries do not have this advantage. Reasons include: (1) Technology development always follows a path from the lower grade toward the upper grade. Introducing advanced technologies from developed country can not only reduce the developing countries' costs in researching and developing new technologies but also save time. (2) The application of advanced technologies in developing countries can generate positive effects on their economic development, which may lead to higher investment ratio than that in developed 
countries. As a result, the return on capital employed in developing countries will higher that in developed countries. (3) Generally speaking, the productivity in industrial section is faster than that in agricultural section. Therefore, in developing countries the rural surplus labors will move toward the industrial section, which will inevitably cause the improvement of national productivity. However, developing countries’ Advantage of Backwardness is merely potential. Its realization is based on developing countries' technological accumulation and fast development. In other words, developing countries have to assimilate and absorb the essence of the introduced technologies and cultivate their own innovation abilities, instead of merely imitating new technologies. In contrast with developed countries, China has Advantage of Backwardness. And China has to depend on its own self-innovation ability, especially enterprises' selfinnovation ability, to realize its Advantage of Backwardness.

\section{Present tax policies in China fail to support the self-innovative enterprises energetically.}

At present, Chinese enterprises' self-innovation abilities do not exert their best effects. Many reasons contribute to this fact. As far as tax system is concerned, present tax policies fail to provide with policy support for enterprise's self-innovation. It chiefly focuses on the income tax and the value-added tax.

\subsection{The income tax}

(1) Domestic enterprises and foreign-funded enterprises have different income taxes. Present income tax system in China is composed of the law of income tax for domestic enterprises (including self-innovative enterprises) and the law of income tax for foreign-funded enterprises. In other words, China adopts different tax systems for domestic enterprises and foreign-funded enterprises respectively. According to the Provisional Regulations of the People's Republic of China on Enterprises Income Tax for domestic enterprises, the name income tax ratio for domestic enterprises is $33 \%$. But the actual ratio is about $23 \%$ or so. In contrast, according to the Income Tax Law of the People's Republic of China for Enterprises with Foreign Investment and Foreign Enterprises, the name income tax ratio is different from $15 \%$, 24\%, to $30 \%$ for the foreign-funded enterprises due to their different registered regions. And their actual ratio is about $11 \%$ or so (Genliang Jia, 2004).

Many problems exist in China's present separated tax system. Firstly, present tax system is not in accord with the principles of WTO. One of the WTO principles is the national treatment principle, which aiming at avoiding foreign-funded enterprises' low taxes than that of domestic enterprises in similar industry. However, the present problem is the "super national treatment" enjoyed by foreign- funded enterprises in China. Foreign-funded enterprises have lower income tax ratio than that of domestic enterprises. Besides, they enjoy favorable treatment in income tax. For example, the productive foreign-funded enterprises are free from income tax for two years since their first profitable year if they operate more than ten years. And in the successive third, fourth, and fifth year, they merely bear half of income tax. Secondly, present tax system is not in accord with the principle of fair competition. In the income tax aspect, foreign-funded enterprises benefit from more favorable treatment than domestic enterprises, what means kind of discrimination toward the later, which betrays the principle of fair competition in market economy. Foreign-funded enterprises and domestic enterprises bear different taxes. Their difference in actual tax burden even reaches more than 10 percent. As a result, domestic enterprises face an unfair competitive environment, which severely affects their existence and development. Besides, this fact may lead to unsatisfactory emotions in domestic enterprises.

(2) The law of income tax for domestic enterprises treats the self-innovative enterprises and common enterprises equally. Self-innovative enterprises have to invest amounts of capital in research \& development. They face unpredictable risks of failure. Once they fail, all investments will lose. Therefore, if domestic enterprises focus on short-term profits and their investments in research \& development are not allowed to be deducted from their income taxes in China, these enterprises will lose motivation in self-innovation. Data show that in China domestic enterprises merely input $0.56 \%$ in research \& development but in developed countries about $5 \%$ or so (Keyi Bi, 2006).

\subsection{The value-added tax}

According to the tax base, there are three types of value-added taxes. The first type is productive value-added tax. In calculating this kind of tax, the assets and other capitals purchased by enterprises are not allowed to be deducted from the added value. The second type is income value-added tax. In calculating this kind of tax, the productive materials purchased by enterprises can be deducted from the added value, which is similar to productive value-added tax. Besides, the fixed assets can be deducted as costs from added value in form of depreciation. The third type is consumptive value-added tax. In calculating this kind of tax, the value-added tax equals the result of sales income detracting middle productive materials and fixed assets purchased at the same time.

China demands for productive value-added tax that connects closely with the capital composition of industry. In the industry with high capital composition, such as industries with more self-innovative enterprises, enterprises usually have more fixed assets purchased from foreign countries. Because the value-added taxes in these fixed assets are not allowed to be deducted, these enterprises usually have to burden higher taxes than that in other industries. As a matter of fact, this tax system affects social investments in high-tax industry, which will hurt the adjustment and optimization of 
national economic structure, and the transform of economic growth way. As far as present situation in China is concerned, the optimization and upgrade of economic structure and the transform of economic growth way can be realized by investing more in self-innovative enterprises, such as updating present equipments or reforming present technologies in enterprises. However, the productive value-added tax makes enterprises burden more taxes for updating equipments, reforming technologies, and introducing advanced techniques. Besides, the higher risks in innovation restrain enterprises' motivation in innovation, affecting the optimization of national economic structure.

\section{Tax policies and regulations in foreign countries that support self-innovative enterprises}

Developed countries lay more stresses on enterprises' innovation. Many countries are inclined to provide with favorable tax treatments for innovative enterprises. Here, this paper summarizes the favorable tax policies and regulations for innovative enterprises in America, Germany, and Japan. China can take references from their reasonable policies to reform its tax system (Why we choose these three countries is for their representative. America and Germany have caught up with and surpassed England since their system innovation in late 19th century. Japan has stepped into the list of developed countries after the World War II. Besides, even at present, these three countries still provide with favorable treatments for their innovative enterprises. Therefore, they are representative in the aspect of favorable tax policies).

(1) The tax deduction for innovative enterprises. According to the Law of Tax for Economic Revival issued by USA government in 1981, taxpayers can deducted the expenditure in trade- or commerce- related researches or experiments from taxes as costs. If the expenditure in one year exceeds the expenditure in former three years, 25 percent of the increasing expenditure can be deducted. If the enterprise does not make profits or has no income tax in one year, the increasing expenditure can be deducted from former three years or later seven years. And the longest period for tax deduction can reach fifteen years. If an enterprise invests in updating or reforming technologies and equipments, 10 percent of investment can be deducted from supposed income tax in one year.

According to Japan's Tax Deduction for Adding Expenses in Experiments and Researches, as an enterprise's added expenses in researches exceed the highest in previous time, 20 percent of added expenses can be deducted from income tax (the highest deduction ratio can reach 10 percent of legal person's income tax). In the Law of Enhancing Small- and Medium-Enterprises' Technology Base, 6 percent of expenses in technology development in small- and medium-enterprises can be deducted from income tax (the highest deduction ratio can reach 15 percent of legal person's income tax). And 70 percent of the increasing fund in enterprises' technology development can be deducted from income tax. As expenses in experiments and researches are higher than the highest in previous time, 20 percent of increasing expenses can be deducted from income tax. And 70 percent of expenses in purchasing machines, equipments, raw materials for scientific and technological research \& development can be deducted from income tax.

Germany has also set up policies for deducting innovative enterprises’ income tax. For example, since 1984 Germany has begun to provide with especially favorable treatments for small- and medium- innovative enterprises. Today, this policy has been changed. Most small- and medium-innovative handcraft enterprises are free from sales tax. But if the sales reach 32,500 Mark, instead of former 25,000 Mark, enterprises have to pay sales tax. After the unification, in eastern Germany if the sales reach 1,000,000 Mark, instead of former 150,000, enterprises have to pay sales taxes. And the lowest income tax ratio is merely 19 percent.

(2) The accelerated depreciation of fixed assets in innovative enterprises can shorten the fixed assets' legal employing age. According to the Law of Tax for Economic Revival, the legal employing age of equipments for scientific researches is three year, or machines five years, and for workshops and buildings ten years. At the same time, it simplified the way of depreciation. If enterprises donate their equipments and machines for scientific researches to high colleges and non-profitable institutions that focus on scientific researches, relevant expenses can be deducted from enterprises' income taxes as donation.

Germany has also set up specific policies for the depreciation of fixed assets. The fixed assets in scientific research \& development can enjoy special depreciation policy. For example, in Germany for the environment-protective equipments in high-tech industry, the depreciation ratio of moveable assets is 50 percent, and that of fixed assets is 30 percent. And the depreciation ratio of equipments in small- and medium-innovative enterprises is increasing from 10 percent to 20 percent.

According to Japan's Tax Deduction for Adding Expenses in Experiments and Researches, in the science and technology developing zone, the high-tech enterprises that have more than 1,000,000,000 Japanese Yuan assets follow common rules of depreciation for their new fixed assets used for research \& development. Besides, in first year, the new purchased assets can enjoy special depreciation ratio. For certain special industries and items, the depreciation ratio can even reach 55 percent. The equipments introduced or purchased by Japan's important branches or industries can depreciate half of their values, and can be deducted from the total profits.

(3) Make best use of favorable tax policies that encourage venture investment and help innovative enterprise to gain financial support. According to the Law of Tax for Economic Revival in USA, for venture investment enterprises, they can enjoy lower taxes and their investments can be deducted as costs before taxation, which can decrease venture 
investment enterprises' risks, income taxes, and their employees' individual income taxes, reducing their risks in ventures and businesses.

The government support in Germany for enterprises' technology innovation, first of all, focuses on capital investment. Germany is one of countries that invest highest capital in science and technology researches and innovations. Among these investments, one third is coming from government directly. And the financial support from government chiefly focuses on universities, scientific researching institutions, state laboratories, and other important fields and subjects. Besides, the government provides with many favorable treatments in the aspect of taxation concerning with these investments. For example, innovative enterprises and researching institutions are free from taxes even they gain profits. And enterprises sponsored by the government are also free from taxes.

\section{The countermeasures and suggestions on the reform of tax system in order to encourage enterprises to invest} more in self-innovation.

In order to exert China's Advantage of Backwardness thoroughly, China should provide with more policy support for self-innovative enterprises, building China into an innovative country. According to the international standard, the innovative country is such a country that invests 2 percent of its GDP in research \& development. But in China this index was only 1.3 percent in 2005. Therefore, to enhance the ability of self-innovation is still the tough work of Chinese enterprises. In order to encourage enterprises to invest more in self-innovation, this paper puts forward following countermeasures and suggestions for the reform of tax system.

\subsection{The countermeasures and suggestions on the reform of income tax}

(1) Equalize the income taxes for foreign-funded enterprises and domestic enterprises. Differences in income taxes make domestic enterprises lag behind in technology update, scale expansion, and further development. To equalize the income taxes means China must constitute a general Law of Income Tax that is not only in accord with the WTO principles but also meeting China's needs for socialist market economy development. By this way, it can thoroughly change present situation in which foreign-funded enterprises and domestic enterprises shoulder different taxes. Besides, it can help to create a fair and reasonable competitive environment for domestic enterprises' existence and development. And it also provides with more feasibility for enterprises investing more in self-innovation.

(2) Encourage enterprises to improve their self-innovation by favorable income taxes. In this aspect, we can take references from the successful experiences of developed countries, such as America, Germany, and Japan. In specific, we can take three points into consideration.

(1) Permit self-innovative enterprises to deduct their actual total expenses spent in technology development from their income taxes in one year. If in the same year the actual total expenses exceed the income taxes, more expenses can be deducted from the income taxes in the future. (2) Allow self-innovative enterprises to quicken the depreciation of their fixed assets used for research \& development, what can inspire enterprises' motivation in investing more in research \& development. (3) Permit self-innovative enterprises to deduct the salaries of researchers and relevant employees' from the income taxes in one year.

\subsection{The countermeasures and suggestions on the reform of value-added tax}

In the value-added tax aspect, the best way is to transform the type of value-added tax. In other words, it is to turn productive value-added tax into consumptive value-added type. As we calculate the consumptive value-added tax, the semi-finished products and the fixed assets purchased at the same period can be deducted from costs. Therefore, it is proper for self-innovative enterprises that may purchase many priceless fixed assets. Besides, if self-innovative enterprises purchase or build fixed assets, or develop virtual assets by themselves, relevant expenses can be deducted from the costs. For example, expenses in machines, equipments, and virtual assets can be deducted from costs. But expenses in buildings and workshops can't be deducted from costs. This tax arrangement can encourage self-innovative enterprises to invest more in introducing or updating technologies and equipments. Moreover, it is simpler and more feasible.

\subsection{The suggestions for the government}

The favorable policies provided by government for self-innovative enterprises in fields of income tax and value-added tax may generate certain negative effects. For example, enterprise may illegally take advantages over government's tax policies, which will cause loses in national finance. Therefore, it is necessary for government to constitute special policies to supervise enterprises' behaviors. For example, the government can set up strict policies for taxation. Once illegal activities are identified, enterprises will be punished severely. Besides, they will pay taxes evaded formerly. And they may even be charged for money many times of taxes evaded. For another instance, the government can impose detailed accounting rules on enterprises, and ask enterprises to perform individual accounting in different departments.

\section{References}

Bi, Keyi. (2006). Revelation from American enterprises increasing investment in innovation. China Economy Weekly. 
Oct.

Deng, Yu. (2005). Unified tax reform should not be blocked by the interests of transnational companies. http://finance.sina.com.cn, 15th, Jan.

Jia, Genliang. (2004). Evolutionary Economics ------ Source of Economics Revolution. Taiyuan: Shanxi People’s Publishing House.

Jiang, Jingfa. (2002). Researches on Finance and Tax Policies for High-Tech Industrialization Development. Beijing: China Financial \& Economic Publishing House.

Li, Shujie. (2003). Viewpoints on the transformation of China's value added tax system. Theory Horizon. No.6. Zhu, Gaofeng. (2005). Self-innovation: integrate technology with economy. Guangming Daily. 13th, Nov. 